\title{
A202 時系列噴流拡散火炎画像の輝度変動の可視化
}

\author{
槌野文博（鹿児島大学院），飯野直子，鳥居修，矢野利明（鹿児島大学） \\ Visualization of Timewise Luminosity Fluctuation of Jet Diffusion Flames
}

Fumihiro Tsuchino, Naoko lino, Shuichi Torii, Toshiaki Yano

\begin{abstract}
Free jet diffusion flame photographs were taken by high-speed video camera. Propane was used as fuel. Flame images are digitized into 24-bit full color images by using commercial software. The digital color image is decomposed into 8-bit images of the Red, Green and Blue components and moreover each component is converted into decimal ASCII data by means of our program. In this study, the Red component luminosity fluctuation is investigated for five different fuel exit velocities. The ASCII data of 3000 frames are stored into Microsoft Excel and the time-averaged value and fluctuation intensity of luminosity are calculated by our program based on the Visual Basic Applications Edition (VBA) in Excel. These results are recomposed into 8-bit BMP images and visualized as the density slicing pseudo color images.
\end{abstract}

Keywords: Image processing, Propane flame, Intensity of luminosity fluctuation

\section{1. 緒論}

近年のパーソナルコンピュータの性能向上は非常にめざま しく、処理可能なデー夕量は格段に堌加し、その処理能力は 飛躍的に向上した。さらに、最近ではパーソナルコンピュー タや周辺機器の価格の低下によって画像処理や演算が手軽に 行えるようになり、アプリケーションソフトも充実してきた ため、解析結果の可視化も簡単になった。また、Microsoft の Visual BASIC を用いて、比較的容易に画像を処理するオ リジナルプログラムが作成できるプログラミング環境も整っ ている。

こうしたコンピュータ環境の発達を背景に、我々はこれま で数百から数干コマの時系列プロパン噴流抬散火炎画像を 画像処理、演算することで、火资の長さや周囲長さなどとい った火炎形状の時間挙動解析 ${ }^{11}$ や輝度や形状の時間変動によ る乱れの特性を検討する試み(-4)などを行ってきた。乱流拡散 火炎は高負荷然焼が可能で、伝播性がないため逆火の心配が なく安全に取り扱うことができる。このため多くの工業用然 焼装置で広く利用されているが、燃焼、特に乱流拡散燃焼は 現象が複雑なため完全な現象把握はできておらず、レーザを 用いた乱れ渦の可視化のや、最新の計測技術を駆使した温度 や速度、涱度変動などの測定による火炎構造の解明 の、これ らの変動成分を統計処理した結果から乱流火资の乱れ特性を 把握しようとする研究りなどが行かれている。

本研究では火炎の輝度情報に注目した。火炎画像の輝度值 は燃焼状態や反応プロセスなどの燃焼現象の一般情報を総括 的に含んでいる。火炎色そのものを扱った研究には、ごみ焼 却プラント用自動燃焼制御装置に対してカラー画像の Red と Blue の成分比から火炎温度を推定寸る方法を組み込んだ 例 ${ }^{8)}$ 、 CIE(国際照明委員会)の XYZ 表色系色度座標で火炎
色を定量化して、プロパン一空気予混合火炎の火炎色と空気 比、ラジカル発光との関係を評価したものなどがある。こ こでは、著者らが開発したプログラムを用いて高速度ビデオ カメラにより撮影されたプロパン噴流拡散火资を Red, Green, Blue に色分解し、それをテキストデータに変换し た。これらのデータを表計算ソフトのプログラム環境を利用 して、3000 コマ分の Red 辉度值加輝度の時間平均と 乱え強さを算出し、Windows 標準のBMP画像として可視化 した。ここでは、これらの方法論および、噴流のレイノルズ 数を 5 段階に変化させた乱流拡散火炎の燃焼挙動との対応に ついて述へる。

\section{2. 荑験装恶およひ画像処理}

実験装置を Fig.1 亿示す。燃料のプロパンを静止空気中に 噴出して抎散火炎を形成した。流量はニードルバルブで調節 し、オリフィス・マノメータで測定した。嘪流レイノルズ数 $\mathrm{R}$ e 使用したステンレススチールチューブのストレートノズルは、 内径が $2.40 \mathrm{~mm}$ ，肉厚が $0.18 \mathrm{~mm}$ である。火炎は一秒間に 500 コマ撮影可能なカラー高速度ビデオカメラ (ナック, HSV. 500）を用いて直接撮影され、S-VHS テープに録画された。

Fig.2 は画像処理の手順を示吕流れ楾図である。録画され たカラー火炎画像は、市販の画像処理装置（三谷商事， WinROOF) で24 ビットのディジタル画像 $(640 \times 480$ Pixels, ただし、撮影領域は $640 \times 200$ Pixels）に変換される。これ らの静止画は我々が開発したプログラム (Image Data Base Management: IDM) によって各々 8 ビットの Red, Green, Blue の成分画像に分解される。これらの各成分画像は、市 販の動画編集ソフト(Adobe Premiere)により動画編集された。 


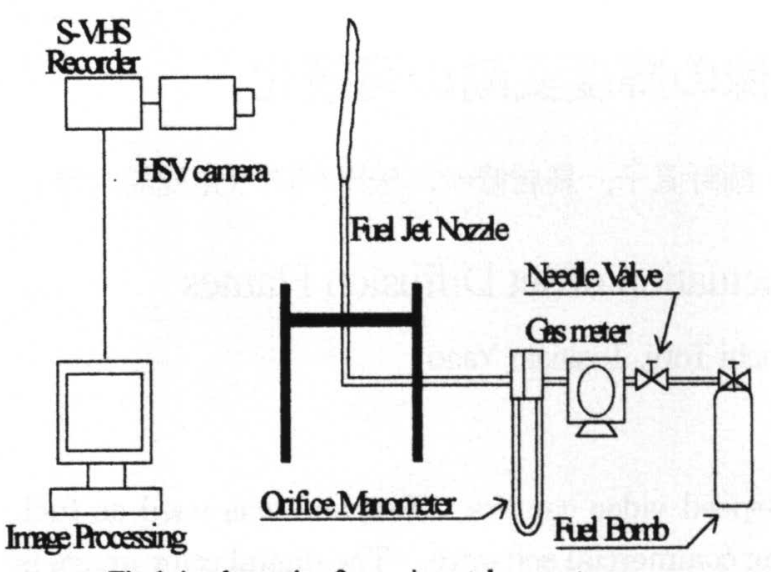

Fig.1 A schematic of experimental apparatus

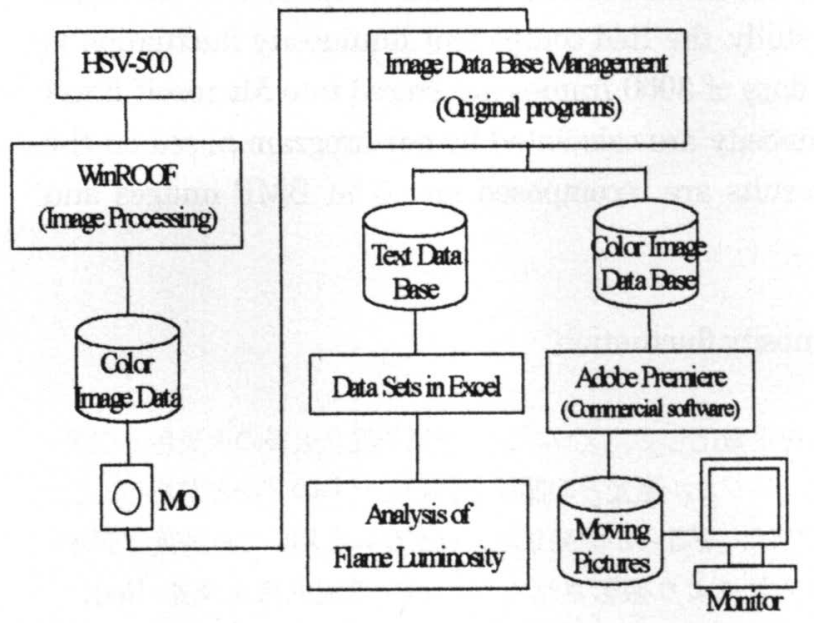

Fig.2 Image processing system

これにより、画質の劣化を招くことなく、パソコンのみでく り返し火炎の時系列挙動の観察が可能となった。色分解後の 8 ピットデータは、IDM によって 10 進のテキスト化処理さ れ、表計算ソフトExclのシート上での行と列が、画像のX, Y 座標に対応する形式でデータベースに保存される。

\section{3. 輝度変動の解析方法}

静止画と動画を検討した結果、Re によって火炎基部の浮 き上がり高さや火炎終端の吹き飛ひ位置、火炎周囲長さや幅 が異なることがわかった。各 Reについて 3000 コマ $(6000 \mathrm{~ms})$ の $640 \times 200$ Pixels 全画素を計算することは、パソコンの性 能上困難であったので、今回は Table1 に示す領域を計算対 象とした。Fig.3 に示すように、ノズル先端は画像の下端に 位置する。ノズル半径方向を $\mathrm{x}$ ，中心軸方向を $\mathrm{y}$ として、ノ ズル中心を原点 $(0,0)$ で表わす。単位は Pixel である。なお、 1 Pixel は $1.66 \mathrm{~mm}$ に対応する。

Red 輝度值の時間変動の解析手順を Fig.4 に示す。表計算 ソフトMicrosoft ExcelのVBA(Visual Basic Applications Edition)環境を利用して、Table1 に示守領域内の各画素の 輝度平均 $\overline{\mathrm{C}}$ を式(1)、変動の強さ $\sigma$ を式(2)て算出した。式(3) で輝度の変動の相対強さ $\sigma_{\mathrm{s}}$ を求める。変動の強さを輝度平 均で割って規格化し、0 255 の 256 階調を持つ 8 ビット画 像へ変換するために 100 をか计た。次に、Exclのシート上
の全画素についての計算結果を 10 進のテキストデータから 8 ビットの濃淡画像へ変換し、Windows 標準の BMP ファイ ルとして保存する。これを ENVI(Better Solutions Consulting Limited Liability Company)でシュードカラー表 示し、可視化した。

\begin{tabular}{|c|c|c|}
\hline Tablel & Analvsis areas & (Pixels) \\
\hline Re & $x$ & $y$ \\
\hline 500 & $-30 \sim 30$ & $10 \sim 350$ \\
\hline 1000 & $-30 \sim 30$ & $10 \sim 350$ \\
\hline 1500 & $-30 \sim 30$ & $10 \sim 350$ \\
\hline 2000 & $-40 \sim 40$ & $10 \sim 350$ \\
\hline 2500 & $-50 \sim 50$ & $10 \sim 350$ \\
\hline
\end{tabular}

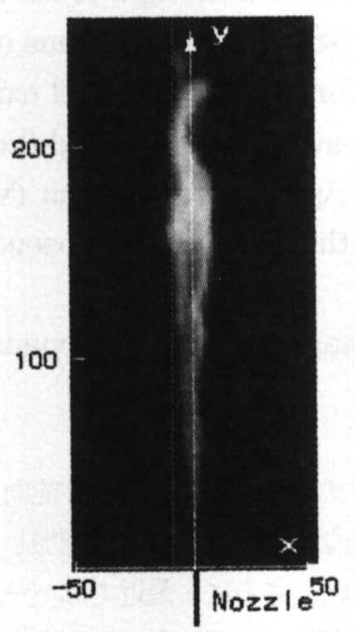

Fig. 3 Flame shape and the coordinate frame $(\operatorname{Re}=500)$

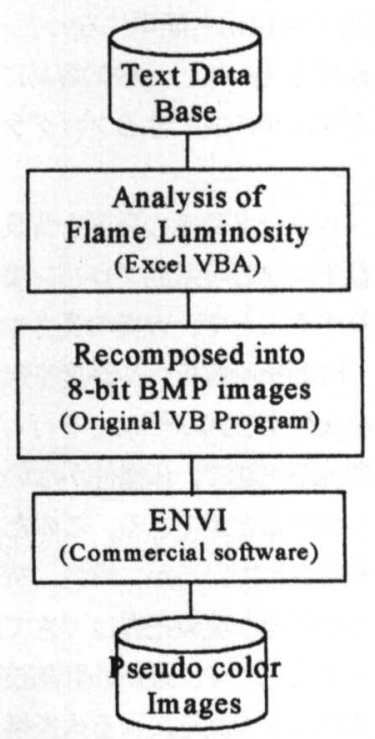

Fig.4 Analysis of flame luminosity fluctuation

$\bar{C}=\frac{1}{m} \sum_{i=1}^{m} C$

$\sigma=\sqrt{\frac{\sum_{i=1}^{m}\left((C i-\bar{C})^{2}\right\}}{m}}$

$\sigma_{s}=\frac{\sigma}{\bar{C}} \times 100$ 


\section{4. 結果と考察}

\section{1 直接写真およびRed 成分画像について}

本研究では直接撮影のカラー火炎画像を解析に使用した。 燃料にプロパンを使用したため、火炎色は黄赤色を呈してい る。これは寸寸加らの連続スペクトルが主に表れていると考 えられる。輝度值は 3 次元火炎の全光路の積分值であるため、 火炎表面の情報を提供するものではない。しかし、撮影され た二次元画像の火炎周囲ではその影響はほとんどない。また、 火炎やす寸が存在する領域は高輝度で、未燃領域や周囲空気 の取り込み洞領域では低輝度を示すことから、これらの輝度 值の変分は総括的な物理的、化学的な燃焼の性質を示してい ると考えられる。

噴流レイノルズ数 Re $=500,1000,1500,2000,2500$ の代 表的な Red 成分画像を Fig.5 に示す。ノズルの位置は画像下 部の黒色直線で示寸。Red 成分は、Green や Blue 成分に比 べて輝度值が高く、背景ノイズとの差が大きいため、閾値処 理を施さなくても火炎形状が比較的はつきりしている。特に $R e=2500$ は燃焼状態が不安定C゙火炎の輝度が低いため、Red 以外の画像では背景との識別が難しい。そこで今回は Red 輝度値を用いて輝度の変動強さについて検討した。

\section{2 各 $\operatorname{Re}$ での燃焼挙動}

Fig.5 およひ動画の観察から、各 Re での噴流抎散火炎の 特徵を简単にまとめる。Fig.5(a)の Re=500 は遷移炎である。 火炎の先端がゅらぎはじめているが、火炎中流までは層流炎 で一定形状を保っている。 Re=1000 以上の Fig.(b) (e)は乱 流炎である。ノズル径が小さいため、すでに浮き上がり火炎 に移行しているが、Fig.5(b), (c)に示す Re=1000, 1500 での 燃焼状態は安定しており、火炎全体の輝度が高い。 $\mathrm{R}=2000$ (Fig.5(d))になると燃焼状热は不安定になりはじめ る。周囲空気の取り込み渦によって火炎の上流での火炎幅は 広がり、下流部が分離してさらに下流へと流されて行く吹き 飛びの周期が明瞭になる。Fig.5(e)の Re=2500 では吹き消え 間近の流速のため、燃焼状態はさらに不安定で火炎全体の輝 度がかなり低下している。常に高輝度を保つ領域はなくなり、

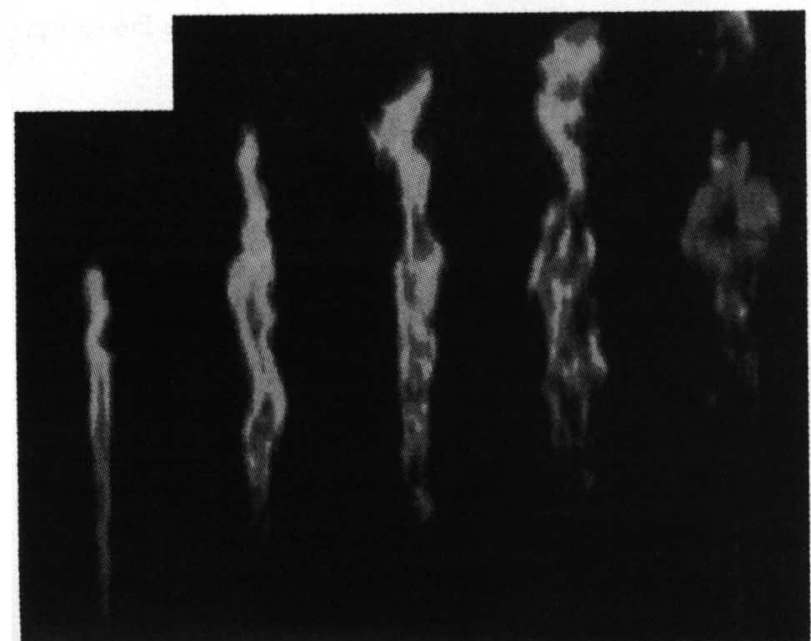

Nozzlel

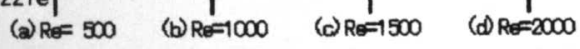

Fig.5 Red component flame images
中流付近で形成された塊状の火炎が下流一流されつつ、周期 的に次の火炎塊が中流付近で発生するという挙動をくり返し ている。

\section{3 輝度平均およひ輝度の乱れ強さ}

各 Re の Red 成分画像の輝度值について、3000 コマ $(6000 \mathrm{~ms})$ の輝度平均 $\overline{\mathrm{C}}($ 式(1))を計算した結果を Fig.6(a) に示 す。Fig.3に示すように、画像下端がノズル出口の位置であ る。直接写真の平均輝度を求めているので、光路長がもっと も長いノズ中心軸上に輝度平均の最高值が表れている。こ の結果は火火炎の存在確率を表わしているものと考えられる。 ノズル先端から火炎終端までを火炎長さと定義すると、一般 に言われているように、完全に乱流火炎に移行した後は燃料 流量を増しても火炎の長さはほとんと変化しないことが輝度 平均画像からも示された。また、各 $R e$ 毎の平均的な浮き上 がり高さや基部幅も明らかとなった。静止画や動画て観察さ れていた通り、Re の増加に伴って浮き上がり高さが大きく なり、火炎基部幅が広がっていることが確がられた。

Fig.6(b)は変動の強さを輝度の平均值で割ることで規格化 した、輝度の変動强さ $\sigma_{s}$ の疑似カラー表示画像である。輝 度の変動強さについて Re による違いは小さい。各火炎の右 側方輝度変動の大きな值を示しているが、これは噴流が完全 な軸対称を保持できなかったためと考えられる。Fig.6(b)を Fig.6(a)および Fig.5 と照らし合わせて考察すると、火炎が 常に存在する領域では変動が小さく、周囲空気の取り込み祜 や、火炎下流部のゆらぎや吹き飛びが起こる領域では乱れて

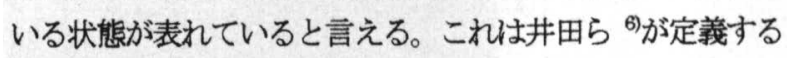
火炎構造の領域 II (然料流と火炎が共存)，吕（火炎領域と 周囲空気流が複雑に混合）にあたるだろう。また、火炎長さ と同様に、火炎が半径方向に広がり得る幅も Re の増加に関 わらずほほ一定である。ここで我々は、Fig.6(a)と(b)から火 炎の領域を以下のように定義する。常に高輝度が保たれてい るため輝度の変動がほとんどなく、Fig.6(b)で黒く表示され る領域を領域 $A$ 、領域 $\mathrm{A}$ の外側に位置し、平均輝度值 31 以 上の領域を領域 $\mathrm{B}$ 、領域 $\mathrm{B}$ のさらに外側で、もはや平均輝度 值は背景值と同程度のレベルであるが、時々火炎が存在し、 輝度の変動強さが 51 以上の領域を領域 $\mathrm{C}$ とする。 $\mathrm{R} e=500$ 〜1500 について、領域 A は Fig.6(b)で各ノズル中心軸を中 心として、Re=500 では幅 $(x w)=14$, 高さ $(y h)=212 、 R e=1000$ のときは $\mathrm{xw}=20, \mathrm{yh}=265 、 \mathrm{Re}=2500$ は $\mathrm{xw}=22, \mathrm{yh}=298$ であ る。領域 A の幅は輝度平均值が 170 以上、高さは 140 以上 の部分にあたる。領域 A には常に火炎が存在し、燃焼状態 は安定していると考えられる。一方、Re=2000 になると火 炎全体の輝度の低下とともに、火炎の浮き上がり高さの変動 が大きくなっていると考えられる。領域 A は減少し、ノズ ル中心軸上にも領域 B が表われている。さらに、 $R=2500$ になると、動画の観察から予測された通り、常に火炎が保持 される領域 A はなくなり、燃焼がかなり不安定になってい ることが示された。このように、直接撮影の火炎画像から求 めた輝度の変動強さは火火炎の燃焼状態を理解するために利用 することが可能である。これは実用の燃焼器こおける燃焼状 

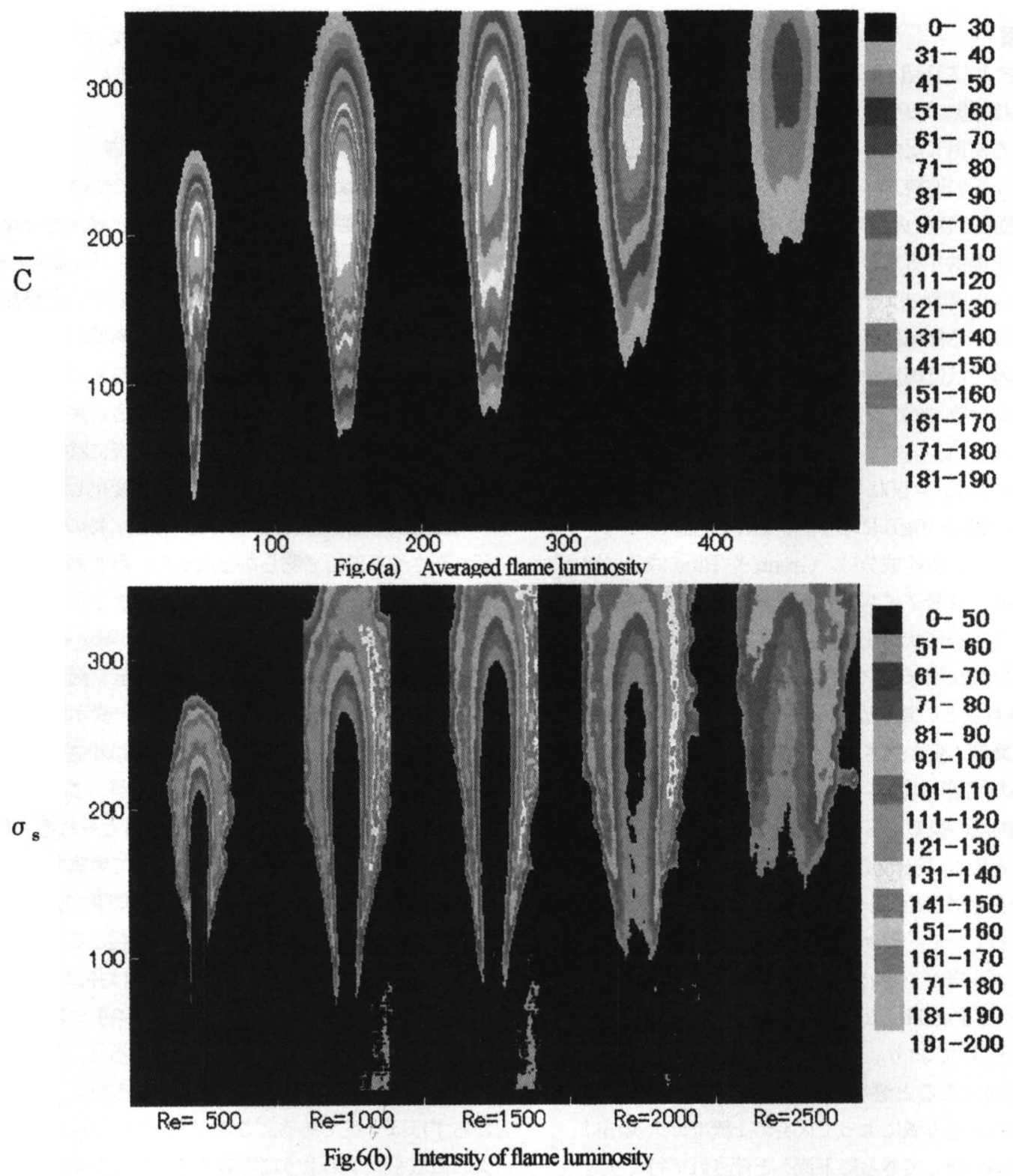

態のモニタリングに適用できる。

\section{5. 結論}

プロパン噴流拡散火炎を、噴流レイノルズ数を5段階に変 化させて、高速度ビデオカメラで撮影した。各 Re の火炎に つて 3000 コマの画像処理、演算およひ動画編集を行い 火炎の輝度平均と輝度の変動強さを求めた。その結果を BMP 画像に変換して、疑似カラー処理した画像を作成した。輝度 変動を火咨の総括的な乱れ状態を表わす一種のパラメー夕と みなし、疑似カラー画像と火炎の挙動とを対比して考察した 結果、以下の知見が得られた。

1. 輝度平均画像を用いて、ある Re の火炎についての平均 的な火炎長さや火炎基部幅などの火炎形状や、浮き上がり高 さといった值を得ることができる。

2. 輝度の変動強さは Re の変化にはあまり影響を受けない が、火炎外周の周囲空気の取り込夕洞や火炎下流部のゆらぎ や吹き飛びといった、火炎の乱れを良く表わす。

3. ノズル出口近傍の輝度の乱れ強さは、燃焼状態を判断す
る指標となり得ることが示唆された。

\section{参考文献}

1) S. Torii and T. Yano, J. Flow Visualization \& Image Processing, 15(1998), 81

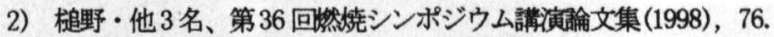

3) S. Torii - 他 2 名, Proc. $5^{\text {th }}$ ASME-JISME Thermal Eng. Conf. (1999), AJTE99-6329.

4) N.Iino - 他 3 名, Proc. The $2^{\text {nd }}$ Pacific Symposium on Flow Visualization and Image Processing (1999), PF069.

5）㙁路·他 3 名、機論 (B), 57, 544(1992)， 4016.

6) 井田・大竹、機論 (B), 56, 531(1990), 3514.

7) 井田・大竹、機論 (B), 61, 582(1995), 744.

8）黑崎·他6名、川崎重工技報，90(1985)，20.

9）伊藤・他 3 名、機掄 (B)，56，531(1990)，3508. 